know where the effect of lighting installations and type of street surface visibility is being investigated, where retirement policies for industry are considered, what goes on in the Centre for Urban Studies, or what are the publications on smoking from the Department of Public Health and Social Medicine, Edinburgh, otc.

\section{Films on Natural History Subjects}

The Intelligence Unit of the Council for Nature has recently issued a list of $16-\mathrm{mm}$. films on natural history subjects, Part 1: The British Isles and Europe. The list has been prepared for the benefit of natural history societies, teachers and others wishing to prepare programmes and educational courses with a natural history content. Films aimed at very young children are omitted and those for children aged between 9 and 15 are indicated. Films are listed in the general headings of: world of life series, secrets of life series, secrets of nature series; ecological films; films on British regions; Europe; birds; fish, reptiles and amphibians; invertebrates and plants. Part 2 will be prepared during 1962 and will cover the rest of the world. Details are supplied of the distributors, whether the films are sound or silent, or black-andwhite or colour, running times and whether or not teachers' notes are supplied. The cost of hiring these films is indicated when necessary. Copies of the list are available from the Council for Nature, 41 Queens. gate, London, S.W.7.

\section{County Naturalists' Trusts}

Tre Council of Nature reports that, during 1961, naturalists trusts have been founded in Glamorgan, Sussex, Hampshire and the Isle of Wight, Devon, Dorset, Suffolk, Gloucestershire and Derbyshire (News for Naturalists, 3, No. 2; January 1962). In addition, the West Wales Field Society has decided to turn itself into a naturalists' trust. Plans for trusts are also going forward in Northumberland, Durham and the Lake District, and discussions are taking place in several other countries. All counties south and east of a line drawn along the northern and western borders of Yorkshire, Derbyshire, Staffordshire, Worcestershire, Gloucestershire, Somerset and Devon are now covered by County trusts, except for Northamptonshire, Nottinghamshire, Somerset and Wiltshire.

\section{Project Mohole Exhibition at the Geological Museum}

THE Project Mohole is featured in a special display at the Geological Museum, Exhibition Road, South Kensington, London, S.W.7. The display provides background information on the American plan to drill through the Earth's crust underlying the ocean to the Mohorovičic discontinuity and to the mantle beneath. The 'Moho' is the level, some $20,000 \mathrm{ft}$. below the deep ocean floor, at which there is a marked change in the velocity of earthquake waves, and is taken to be the base of the Earth's crust. The project is being carried out for the U.S. National Academy of Sciences National Research Council by the American Miscellaneous Society (see Nature, 184, $140 ; 1959)$. The central feature of the exhibit is a vertical 25-ft. scale section of the Earth's crust beneath the ocean with a model of the drilling barge and drill-string to the same scale. A cut-away globe summarizes the present state of knowledge of the Earth's interior, and a large coloured diagram shows the constitution of the continental and oceanic areas of the Earth's crust. Details are also given of the methods used in the successful experimental drilling carried out during 1961 in the Pacific Ocean in $11,700 \mathrm{ft}$. of water. A full-sized model of the diamondarmed drilling bit used in the experimental drilling is accompanied by specimens of the industrial diamonds used in this type of bit. The display will remain on show until the completion of the project, and it is intended to incorporate results as they become available.

\section{The South African Museum}

In the annual report of the South African Museum for the period April 1, 1960-March 31, 1961, reference is made to forthcoming building operations which will give additions to the main building and a new administrative block (Pp. vi +34 . Cape Town: South African Museum, 1961). In view of the restoration of the old Supreme Court to house the Cultural History Museum, it is suggested that it is linked with Koopmans de Wet House to form a separate entity with its own Board of Trustees and Director. With the aid of a trawler, the marine biologists at the Museum were able to obtain some valuable results in their research on tunny biology. Other research projects include serial sectioning of the skulls of many Deinocephalia and the Middle Triassic dinosaurs and advanced mammal-like reptiles. A large diorama depieting the bird life of Malgas Island, and exhibition on Bushman music and "Cape Town 1910-1960" have been completed during the year. As with so many recent reports on museum work, the format of cover, printing and illustrations are modern and attractive.

\section{Computer Methods, Machines and Services}

THE proceedings of the sixth congress on theoretical and applied mechanics, held at Delhi in December 1960 , have just appeared in print (Pp. $x i+316$. Kharagpur: Indian Society of Theoretical and Applied Mechanics, Indian Institute of Technology). The papers range from mathematical analyses of magneto-hydrodynamic shock-waves to practical studies of flange connexion design for pressure vessels. An addendum contains material on a symposium entitled "High-speed Computation Methods and Machines" that was included in the programme of the meeting; it dealt with both analogue and digital computation, and gives a picture of some of the computing resources available in India. The January issue (Nos. 15-16, October 1961-January 1962) of the Bulletin of the Provisional International Computation Centre, Rome, contains interesting papers on machine translation and on learning machines. The Bulletin, of which this is the fifteenth issue, performs a useful service in documenting European computer activities and in providing detailed information on the facilities available in the various laboratories.

\section{Age of Leads in Britain}

RECENT work on the abundance of lead isotopes in British galenas suggests the existence of at least six distinct periods of mineralization. These were: Caledonian, probably mainly of Middle and Upper Silurian age; Devonian; Lower or Middle Carboniferous; Hercynian, probably Lower Permian; Mesozoic, probably Upper Triassic; Upper Mesozoic, probably Upper Jurassic or Cretaceous. It is interesting to find that there is no isotopic evidence for Tertiary sulphide mineralization within the British 